\title{
South American Cane Toad (Rhinella marina) Found on Great Guana Cay, Abaco, The Bahamas
}

\author{
Scott Johnson ${ }^{1}$ and Deon Gibson ${ }^{2}$ \\ ${ }^{1}$ Bahamas National Trust, East Bay Street, Nassau, Bahamas, P.O. Box N-4105 (sjohnson@bnt.bs) \\ ${ }^{2}$ Bakers Bay Golf and Ocean Club, Front Street, P.O Box AB-20766, Marsh Harbour, Abaco, Bahamas (deondgibson@gmail.com)
}

$\mathrm{O}$ n the night of 15 March 2018, Llewelyn Kellman, an employee at the Baker's Bay Ocean and Golf Club on Great Guana Cay, Abaco, The Bahamas (26²1'10.73”N, $\left.77^{\circ} 8^{\prime} 44.43^{\prime \prime} \mathrm{W}\right)$, noticed a strange anuran near a pond adjacent to a fruit orchard. He sent photographs to a co-worker (the second author), who asserted that they were South American Cane Toads (Rhinella marina). The photographs then were sent to the first author, who confirmed the identification of the animal. The female toad was retrieved by the first author on 3 May 2018 from the edge of a freshwater pond (26⒋ $\left.48.36^{\prime \prime} \mathrm{N}, 77^{\circ} 9^{\prime} 36.29^{\prime \prime} \mathrm{W}\right)$ and euthanized. Subsequent monitoring revealed no other toads, egg masses, or tadpoles.
South American Cane Toads are native to South America but have been introduced to various countries around the world, including Australia, Hawaii, Puerto Rico, Guyana, Martinique, Jamaica, Grenada, and Barbados (e.g., Shine 2010; Beard et al. 2018). South American Cane Toads secrete powerful skin toxins that can be fatal if ingested by a putative predator; consequently, these invasive toads can present a substantial threat to native wildlife (e.g., Shine 2010; Wilson et al. 2011). Because of its ability to successfully colonize new habitats and the danger it poses to native wildlife, the South American Cane Toad is considered one of the most invasive animals on earth (Lowe et al. 2000).

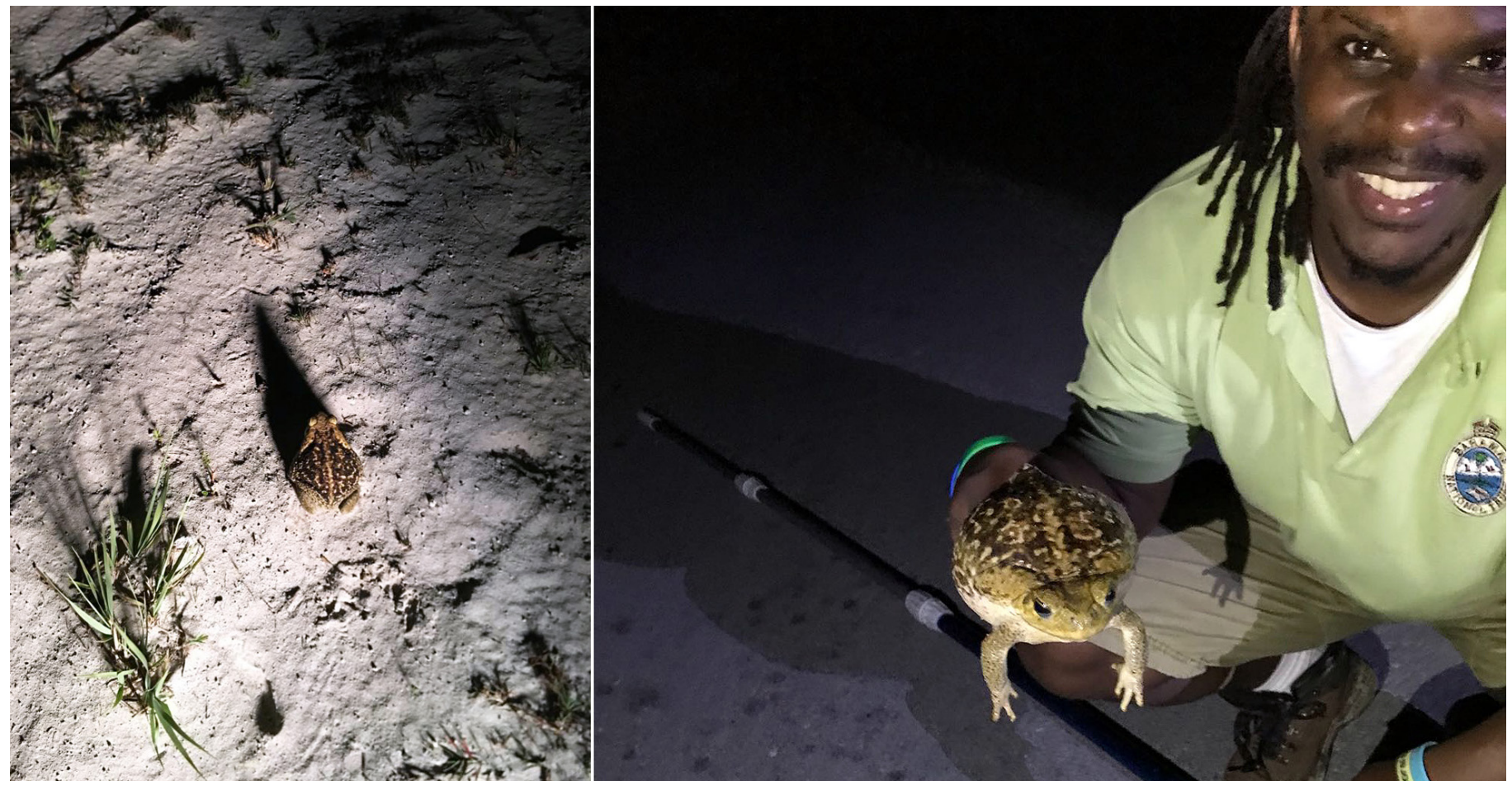

Fig. 1. Female South American Cane Toad (Rhinella marina) encountered at Bakers Bay Resort and Ocean Club on Great Guana Cay, Abaco, The Bahamas, on 15 March 2018 (left); the senior author with a female South American Cane Toad captured in the same area where it was originally located. Photographs by Llewelyn Kellman (left) and Dr. Livingstone Marshall (right). 
South American Cane Toads were first seen in The Bahamas on a private property on Treasure Cay, Abaco in 2006. That individual was captured and destroyed. In 2009, a toad sighting was confirmed on Baker's Bay, Great Guana Cay, also in the Abacos. Photographs were sent to Sandra Buckner, who confirmed its identity. Since 2009, no other sightings have been reported at Baker's Bay. Another confirmed sighting of South American Cane Toads in The Bahamas was on 15 June 2011 on New Providence, when a gardener working at a private residence at Lyford Cay, a gated community in the western section of the island, saw the toads. Photographs again were sent to Sandy Buckner, who confirmed their identity. In 2013, large numbers of toads were seen in the Lyford Cay community. That toad population appears to be confined to the gated community, where active monitoring and removal has been occurring since 2013 . Although we do not know how South American Cane Toads arrived in the areas mentioned, their introductions are most likely the result of unchecked shipping containers carrying plants from other countries.

\section{Acknowledgements}

We thank Sandy Buckner for her meticulous documentation and help in tracing the first sightings of South American Cane Toads in The Bahamas. We also thank Lisa Gorospe and David Knowles for information and photographs (not shown) of toads on Abaco and New Providence, and the staff at Bakers Bay for their help with toad monitoring.

\section{Literature Cited}

Beard, K.H., S.A. Johnson, and A.B. Shields. 2018. Frogs (Coqui Frogs, Greenhouse Frogs, Cuban Tree Frogs, and Cane Toads), pp. 163-192. In: W.C. Pitt, J.C. Beasley, and G.W Witmer (eds.), Ecology and Management of Terrestrial Vertebrate Invasive Species in the United States. CRC Press, Boca Raton, Florida.

Lowe, S., M. Browne, S. Boudjelas, and M. De Poorter. 2000. 100 of the World's Worst Invasive Alien Species. A selection from the Global Invasive Species Database. The Invasive Species Specialist Group, Species Survival Commission, World Conservation Union, Auckland, New Zealand.

Shine, R. 2010. The ecological impact of invasive Cane Toads (Bufo marinus) in Australia. The Quarterly Review of Biology 85: 253-291.

Wilson, B.S., S.E. Koenig, R. van Veen, E. Miersma, and D.C. Rudolph. 2011. Cane Toads a threat to West Indian wildlife: Mortality of Jamaican Boas attributable to toad ingestion. Biological Invasions 13: 55-60. 